\title{
DISTRIBUTION OF BOVINE HERPESVIRUS 1 IN CATTLE POPULATION AND BULLS FROM CENTERS FOR ARTIFICIAL INSEMINATION AND PRIVATE FARMS IN BULGARIA
}

\author{
Raiko Peshev $^{1}$, Lilly Christova ${ }^{2}$ \\ ${ }^{1}$ National Diagnostic and Research Veterinary Medical Institute, Sofia, Bulgaria \\ ${ }^{2}$ Institute of Biophysics and Biomedical Engineering, \\ Bulgarian Academy of Sciences, Sofia, Bulgaria
}

\section{Abstract}

The aim of the study is determination of the BHV 1 incidence among the bovine population in Bulgaria by using various ELISA tests for antibody detection and different methods for proving viral antigen. Commercial diagnostic ELISA kits were used for screening as well as for confirmation of the antibodies. Serological examination encompassed 2973 serum samples from bovine population in Bulgaria (cattle, calves and bulls) originating from 21 country regions. Total 408 cattle and 150 bulls' samples originating from artificial insemination centers (AIC), commune and private farms from 21 country regions were subjected to virology testing. Identification of isolated viruses was performed using conventional and nested PCRs for BHV $1 \mathrm{gB}$ gene detection. The percentage of positively reacting cattle sera were significantly $(\mathrm{p}<0.001)$ higher $(38.3 \%)$ then that of bulls $(29.3 \%)$ after ELISA testing of 2240 cattle serum samples and 733 bulls' sera. Seven strains with BHV 1 characteristics were isolated from Dobrich, Lovech - 2 strains, Plovdiv, Targovishte, Pazardjik and Svishtov regions after cultivation 408 samples from cattle and calves (buffy coats, nasal, eyes, vaginal swabs, tissues and organs) on cell cultures. Three BHV 1 strains were isolated from Sliven, Shumen and Blagoevgrad regions after examining 150 bulls' samples (nasal, eyes, preputial, semen samples and buffy coats). Confirmation of virus isolation was accomplished using PCR $g B$ gene based primers (amplified $478 \mathrm{bp)}$ The amplicons from 3 bulls isolated strains with the same size and location as the referent Oxford strain were observed. After performance of nested PCR for $\mathrm{gB}$ gen, products with size of $385 \mathrm{bp}$ were obtained in all samples as well as in the referent Oxford strain.

Key words: BHV-1, Bulgaria, serum, tissues, swabs 


\title{
DISTRIBUCIJA BOVINOG HERPESVIRUSA 1 U POPULACIJI GOVEDA I BIKOVA IZ CENTARA ZA VEŠTAČKO OSEMENJAVANJE I PRIVATNIH FARMI U BUGARSKOJ
}

\author{
Raiko Peshev ${ }^{1}$, Lilly Christova ${ }^{2}$
}

\section{Kratak sadržaj}

Cilj ovog rada je odredjivanje incidence BHV1 u populaciji govead u Bugarskoj primenom različitih vrsta ELISA testova za detekciju antitela i različitih metoda za dokazivanje prisustva virusnih antigena. Komercijalni ELISA dijagnostički kitovi su primenjeni kako za skrining tako i za konfirmaciju prisustva antitela. Serološko ispitivanje obuhvatilo je 2973 uzoraka seruma dobijenih od populacije goveda iz 21 regiona u Bugarskoj (goveda, telad i bikovi). virusološka analiza obuhvatioa je ukupno 408 uzoraka dobijenih od goveda i 150 uzoraka dobijenih od bikova iz centara za veštačko osemenjavanje, državnih i privatnih farmi iz 21 regiona u zemlji. Za identifikaciju izolovanih virusa korićene su konvencionalne i nested PCR metode za detekciju 1 gB gena. Analiza 2240 uzoraka seruma dobijenih iz populacije goveda i 733 uzorka od bikova pomoću ELISA metode pokazala je da je procenat pozivnih reakcija seruma goveda bio značajno $(\mathrm{p}<0,001)$ viši $(38,3 \%)$ nego kod bikova $(29,3 \%)$

Sedam sojeva sa karakteristikama BHV1 izolovano je u oblastima Dobrich, Lovech - 2 soja, u regionima Plovdiv, Targovishte, Pazardjik i Svishtov nakon kultivacije 408 uzoraka od goveda i teladi na ćelijskim kulturama (sloj nataloženih leukocita i trombocita - buffy coat, nazalni bris, bris oka, vaginalni brisevi, tkiva i organi). Tri soja BHV1 izolovana su u oblastima Sliven, Shumen i Blagoevgrad nakon ispitivanja 150 uzoraka od bikova (nazalni brisevi, bris oka, prepucijuma, uzorci sperme i buffy coat). Konfirmacija izolacije virusa vršena je pomoću PCR metode sa prajmerima za multiplikaciju gB gena veličine 478 bp. Uočeni su amplikoni sojeva izolovanih od 3 bika, iste veličine i lokacije kao i referentni soj Oxford. Nakon nested PCR za gB gen, dobijen je proizvod veličine 385 bp u svim uzorcima, kao i u referentnom soju Oxford.

Ključne reči: BHV-1, Bugarska, serum, tkiva, brisevi

Bovine herpesvirus 1 (BHV 1) belongs to the subfamily alpha herpesvirinae, genus varicellovirus of the family Herpesviridae (Roizman et al. 2001) and 
has a narrow specter of hosts in comparison with other representatives of this subfamily having broad range of hosts. A range of clinical signs are observed, depending on the virus introduction and BHV 1 infection route - infectious bovine rhinotracheitis (IBR), infectious pustular vulvovaginitis (IPV), infectious pustular balanopostitis in bulls (IPB) (Gibbs and Rweyemamu, 1977).

BHV 1 infection is initially manifested as a venereal form affecting genital tract in cattle (IPV) and bulls (IPB). IPV infection is characterized by small pustules on the vulva mucosa and caudal parts of the vagina. In IPB, the clinical symptoms are restricted to the mucosa of the preputium, penis and distal parts of urethra.

The virus can cross the placenta to infect the fetus and potentially cause the abortion. It can infect the male genital tract inducing balanopostitis or penopostitit. After initial or reactivated infection of bulls, the virus is shed through the preputium and semen infection occurs in 2 to 7 days (Straub, 1990). The virus spreading can occur through female animals (so-called vertical transmission) (Straub, 1990). The initial period of virus dissemination can prolong for several weeks and during the initial stage of infection, the virus cannot be isolated (Huck et al., 1971). Latently infected bulls can re-excrete the virus in stressful situations (transportation or dexamethasone treatment). The animals usually do not manifest clinical symptoms and can disseminate the virus over a long time period, even for years (Bitch, 1978; Pastoret, 1982). After natural or artificial insemination with the infected semen material for in vitro fertilization, the virus can infect female animals and the risks for national and international spread of the virus is increasing (Kendrick and Mc Entee, 1967).

Identification of latent virus carriers among the bulls requires adequately sensitive and specific serological tests. Usually, the serum neutralization tests (SNT) is used as the gold standard for detecting BHV 1 specific antibodies. Different laboratories apply diverse SNT variants. Positive correlation between duration of serum-virus mixture incubation period and reaction sensitivity is well established. For example, the serum titers are 16 times higher after $24 \mathrm{~h}$ incubation of the serum-virus mixture as compared with titers after $1 \mathrm{~h}$ incubation (Bitch 1978, OIE, 2004). Despite the fact that SNT is highly sensitive and specific; however, it requires cell cultures and sterile conditions. Moreover it is time consuming, laborious and cannot be automated. Thus, variants of ELISA are preferred techniques for detection of BHV 1 antibodies (Van Oirschot, 2000). Commercially available ELISAs are developed for accomplishing the control and eradication programs and their sensitivity is comparatively studied (Kramps et al., 1993).

Detection, isolation and identification of BHV1 is accomplished by the use of cell culture and various methods (Wyler et al., 1989): ELISAs with monoclo- 
nal antibodies for antigen detection (Collins et al., 1988) as well as a range of polymerase chain reactions (PCR) proving $\mathrm{gB}, \mathrm{gC}, \mathrm{gD}$ genes and thymidine kinase (TK) (Wiedmann et al., 1993; Kibenge et al., 1994 and Vilcek et al., 1994). Highly sensitive PCR determining three to five molecules of BHV-1 in bovine semen (Engelenburg, 1993) and nested PCR detecting 0.25-2.5 TCID50 of BHV 1 in bovine semen (Masri et al., 1996) was developed.

The aim of this study is determination of BHV 1 incidence among the bovine population in Bulgaria by using various ELISAs for antibody detection and different methods for detection of virus antigens

\section{MATERIAL AND METHODS}

\section{Serological analysis}

Serological examination of 2973 serum samples from bovine population in Bulgaria (cattle, calf and bulls) originating from 21 country regions was performed. Blood samples were coagulated, harvested, inactivated at $56^{\circ} \mathrm{C}$ for $30 \mathrm{~min}$ and subsequently, antibiotics were added. The samples were frozen at $-20^{\circ} \mathrm{C}$.

Commercial diagnostic ELISA kits were used for screening as well as for the confirmation of the antibodies (Institute Pourquier, France). The readings were performed at $450 \mathrm{~nm}$ optical density (OD) for both reactions.

The screening reaction is based on specific bounding of the antibodies from the examined sample to the BHV1 antigen immobilized on the ELISA microtiter plate. The bound antibodies were detected using the anti bovine immunglobulin $\mathrm{G}$ ( $\operatorname{IgG}$ ) monoclonal antibodies marked by horse-radish peroxidase (HRPO). After addition of chromogen substrate, the presence of BHVlantibodies in the sample results in specific color reaction indicating the seropositive result

Minimal mean OD value of positive control 0.350 and proportion between mean values for positive and negative controls equal or more than 3.5 was adoptedas the criteria for reaction validity.

Percentage of positive $(\mathrm{S} / \mathrm{P})$ samples was determined by the formula:

$$
\mathrm{S} / \mathrm{P}=-\mathrm{OD} 450 \mathrm{~nm} \text { sample - OD } 450 \mathrm{~nm} \text { negative control }
$$

Mean OD $450 \mathrm{~nm}$ positive control - OD $450 \mathrm{~nm}$ negative control

The sera with $\mathrm{S} / \mathrm{P} \leq 45 \%$ were considered negative and with $\mathrm{S} / \mathrm{P} \geq 55 \%$ as positive to BHV 1 antibodies. Sera with S/P between 45 and 55\% were considered doubtful and were retested after 3-4 weeks. 
Verification of the results obtained in screening test was performed in a subsequent confirmation test. Wells with BHV 1 antigen and corresponding wells loaded with control antigen (uninfected cell culture) were used. The sera samples were filled into the both wells. The results were considered valid if a minimal mean OD 450 value for positive control was 0.350 (uncorrected) and the ratio between mean corrected OD 450 value for the positive control and the negative control was equal or greater than 3.5.

The result was obtained after OD correction using the following equation:

$$
\mathrm{OD}_{\mathrm{BHV} 1}-\mathrm{OD}_{\text {control }}=\mathrm{OD}_{\text {corrected }}
$$

where $\mathrm{OD}_{\mathrm{BHV}}{ }_{1}$ wells coated with the BHV 1 antigen, $\mathrm{OD}_{\text {control }}$ uncoated wells

The results were obtained by calculation of sample positive control (S/P) by the ratio:

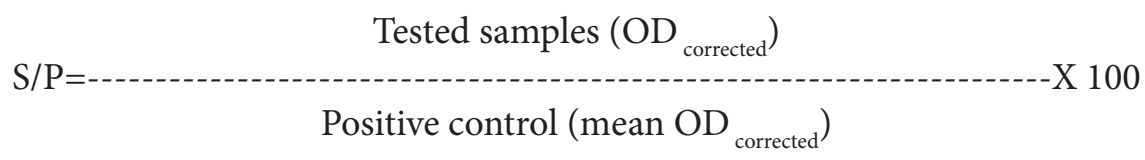

All samples with $\mathrm{S} / \mathrm{P} \leq 45 \%$ were considered negative, with $\mathrm{S} / \mathrm{P}$ between 45 and $55 \%$ doubtful and with $\mathrm{S} / \mathrm{P}>55 \%$ were considered $\mathrm{BHV} 1$ positive .

\section{Virus analysis}

Total 408 cattle and 150 bulls' samples originating from artificial insemination center (AIC), community and private farms from 21 country regions were analyzed. Buffy coats, nasal, eye, preputial and vaginal swabs, as well as samples of the semen, tissues and organs from infected animals were treated by the method of Dilovski et. a.,l (1982) and inoculated onto cell cultures. Primary rabbit and continuous cell lines from calf kidney - Madin-Darby bovine kidney (MDBK) were used for isolation and culturing. Eagle minimal essential medium (E MEM) with Hank's salts were used as growing and maintenance medium. Antibiotics penicillin $100 \mathrm{UI} / \mathrm{mL}$, Streptomycin $100 \gamma / \mathrm{mL}$ and $10 \%$ fetal calf serum (FCS) and 2\% FCS were added as a growing and maintenance medium, respectively. Semi-confluent or confluent cell culture monolayers were inoculated with $0.2 \mathrm{~mL}$ of treated specimens and adsorbed for $2 \mathrm{~h}$ at $37^{\circ} \mathrm{C}$ with exception of buffy coats and semen samples (adsorbed for $1 \mathrm{~h}$ at $37^{\circ} \mathrm{C}$ ). 
After absorption, the cell monolayers were washed and maintenance medium was added. The cytopathic effect was determined microscopically $120 \mathrm{~h}$ after inoculation. Three consecutive passages of cell cultures were performed. Uninfected cell cultures were used as the negative control. The virus titers and serum neutralization titers were determined by the method described by $\mathrm{Di}$ lovski et al. (1982).

Conventional PCR was developed for BHV $1 \mathrm{gB}$ gene for the identification of isolated viruses (Fucsh et al., 1999). Primers $\mathrm{gB}_{1}$ multiplying part from $\mathrm{gB}$ gen at position $883-902$ and $\mathrm{gB}_{2}$ at position $1341-1360$ amplifying product with 478 bp size were used. Nested PCR multiplying BHV 1 gB gen was performed with nested primers $\mathrm{gB} \mathrm{N}_{1}$ at position 899 - 918 and $\mathrm{gB} \mathrm{N}_{2}$ at position 1264 - 1283 creating the product with $385 \mathrm{bp}$ size. The strains DNA isolated from the infected cell cultures and DNA of referent BHV 1 were subjected to electrophoresis in $2 \%$ agarose-gel containing $(1 \mathrm{mg} / \mathrm{mL})$ ethidium bromide. The electrophoresis was carried out at $120 \mathrm{~V}$ for $45 \mathrm{~min}$ in $0.5 \mathrm{TBE}$ buffer (0.045 M Tris borate, $0.001 \mathrm{M}$ EDTA $\mathrm{pH}$ 8.6). As positive and negative controls, the referent BHV 1 Oxford strain and uninfected MDBK cells were used, respectively. To control the contamination, sterile distilled deionized water was added instead of DNA.

\section{RESULTS}

The percentage of positive sera after using the confirmatory test was insignificantly ( $\mathrm{p}>0.05)$ higher than that in the screening test.

Analysis using ELISA revealed that out of 2240 serum samples from bovine population and 733 from bulls the rate of positive cattle serums $(38.3 \%)$ was significantly higher $(\mathrm{p}<0.001)$ then that of the bulls $(29.3 \%)$ (fig.1). 


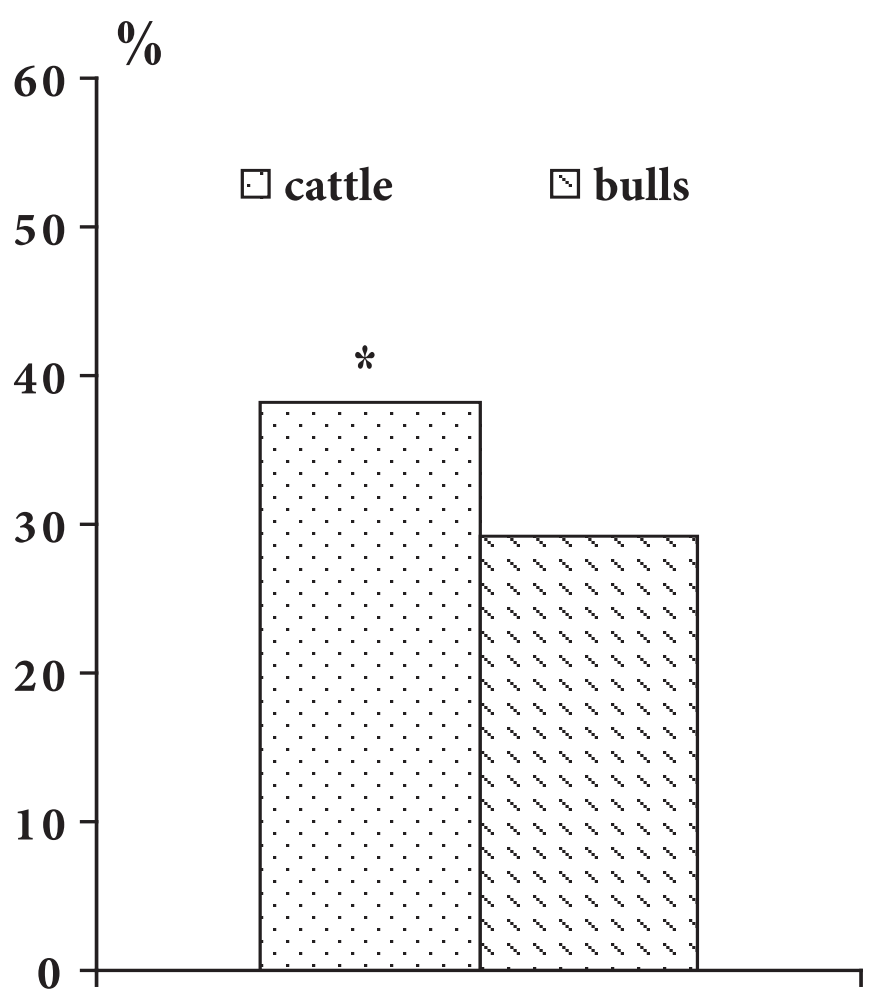

Fig.1. The percent distribution of positive cows and bulls samples after investigation by ELISA confirmatory test.

The percentage of positively reacting cattle and calf serums for different regions varied between 50 and 70\%: Dobrich (72.9\%), Burgas (72.2\%), Pernik (67.6), Haskovo (66.1\%), Lovech (63.0\%), Shumen (54.7\%) Plovdiv (54.1\%); between 30 and 50\% Sliven (47.5\%), Razgrad (47.4\%), Blagoevgrad (42.5\%), Montana (36.9\%), Targovishte (35.8\%), Sofia (35.5\%), V. Tarnovo (33.3\%), and below 30\% Smolian (26.5\%), Gabrovo (15.6\%), Yambol(14.5\%), St. Zagora (12.1\%).

The percentage of positively reacting bulls' sera were as following: Pernik (70.0\%), Yambol (63.6\%), Montana (62.5\%), followed by Sofia region (55.2\%), Pazardjik (53.2\%) Varna (50.9\%), Burgas (50.0\%), ranged between 30 and 50\% in Haskovo, Blagoevgrad, Shumen and Smolian regions and below $30 \%$ in Gabrovo, Sliven, Dobrich and St. Zagora regions.

The mean optical density of sera samples for cows and calves from 16 regions varied between (26.4\% and $44.3 \%)$. For bulls' samples from the same 
regions the mean optical density ranged between ( $87.1 \%$ and $147.6 \%)$. The significantly highest $(\mathrm{p}<0.01)$ OD rate was established in bulls from Smolian, Lovech, Pernik, Varna and Pazardjik regions. In the other investigated regions, the percent was between $65 \%$ and $96 \%$ (table1).

Table 1. The mean OD percent positivity (\%) for investigated cows and bulls for 16 country regions.

\begin{tabular}{|l|c|c|}
\hline \multirow{2}{*}{ Country regions } & \multicolumn{2}{|c|}{ Optical densities percent positivity (\%) } \\
\cline { 2 - 3 } & Cows & Bulls \\
\hline 1. Haskovo & 36.2 & 101.34 \\
\hline 2. Pazardjik & 33.3 & 100.37 \\
\hline 3.Pernik & 29.65 & 112.34 \\
\hline 4. Yambol & 41.34 & 76.27 \\
\hline 5. Sofia & 35.62 & 64.33 \\
\hline 6. Sofia district & 33.79 & 87.67 \\
\hline 7. Burgas & 23.93 & 84.37 \\
\hline 8. Gabrovo & 29.39 & 94.31 \\
\hline 9. Montana & 35.1 & 98.31 \\
\hline 10. Dobrich & 35.64 & 93.18 \\
\hline 11. Blagoevgrad & 36.87 & 89.64 \\
\hline 12. Smolian & 28.47 & 147.63 \\
\hline 13. Shumen & 38.83 & 93.6 \\
\hline 14. Lovech & 37.71 & 103.94 \\
\hline 15. Sliven & 26.35 & 87.12 \\
\hline 16. St. Zagora & 37.81 & 96.39 \\
\hline
\end{tabular}

Proportional distribution of positively reacting cattle and calf serums was significantly $(\mathrm{p}<0.01)$ higher than that of the bulls in all years of investigation, except for 2009 and 2011 (fig.2). 


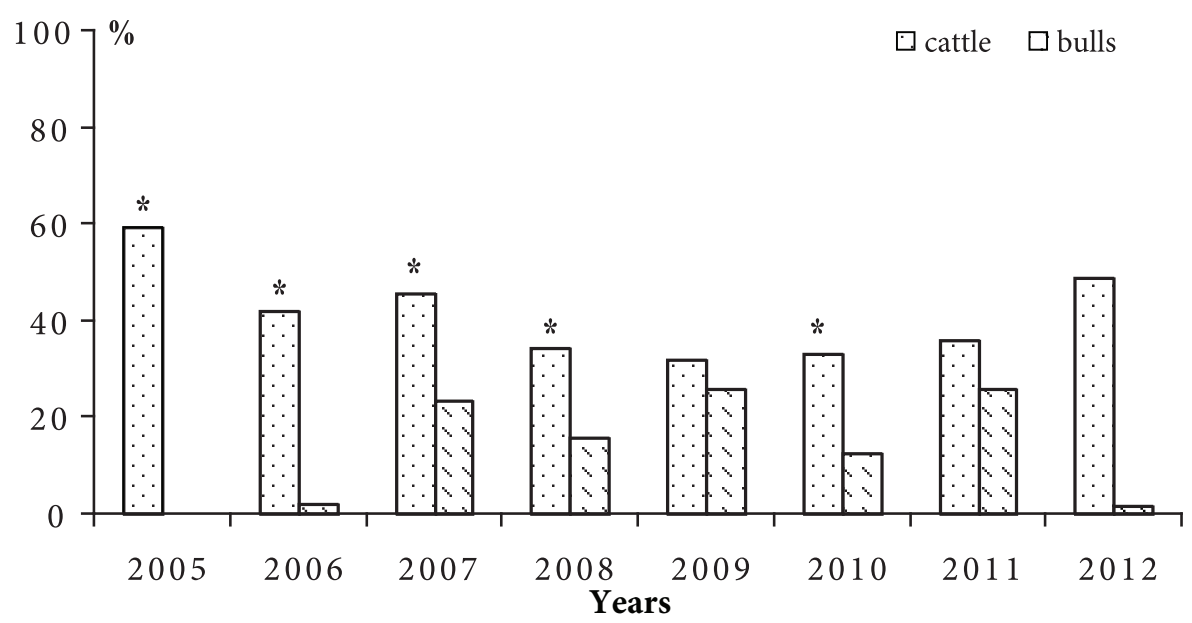

Fig. 2. The percent distribution of positively reacted bovines for eight years. With * are marked statistically significant differences $(\mathrm{p}<0,01)$ between cattle and bulls.

After cultivating 408 samples originating from cattle and calves (buffy coats, nasal, eye, vaginal swabs, tissues and organs) on cell culture, seven strains manifesting BHV 1 properties were isolated from Dobrich, Lovech - 2 strains, Plovdiv, Targovishte, Pazardjik and Svishtov regions.

Three BHV 1 strains were isolated from Sliven, Shumen and Blagoevgrad regions after examining 150 bulls' samples (nasal, eye, preputial, semen samples and buffy coats).

The morphological characteristics were typical for BHV 1 . In primary and permanent cell cultures, the cytopathic effect was visible $12 \mathrm{~h}$ after inoculation. Rounding and detachment of cell cultures were advanced 18-20 h later, and the number and space of clusters with damaged cells increased and vacuolation and granulation of cells were evident. A lot of spherical cells undergoing ballooning degeneration linked with cytoplasmic bridges and progressive detachment of cells after $72 \mathrm{~h}$ were visible. Single degenerating cells and full cell detachment 96-120 h after inoculation were observed.

Confirmation of virus isolation was accomplished using PCR $g B$ gene $b a$ sed primers (amplified $478 \mathrm{bp}$ ) The amplicons from 3 bulls isolated strains with the same size and location as the referent Oxford strain were observed. After performing nested PCR for gB gen, products $385 \mathrm{bp}$ in size were obtained in all samples as well as in the referent Oxford strain. Virus amplification was established neither in uninfected MDBK cells nor in sterile distilled water, which were used as negative controls in conventional and nested PCRs (fig. 3). 


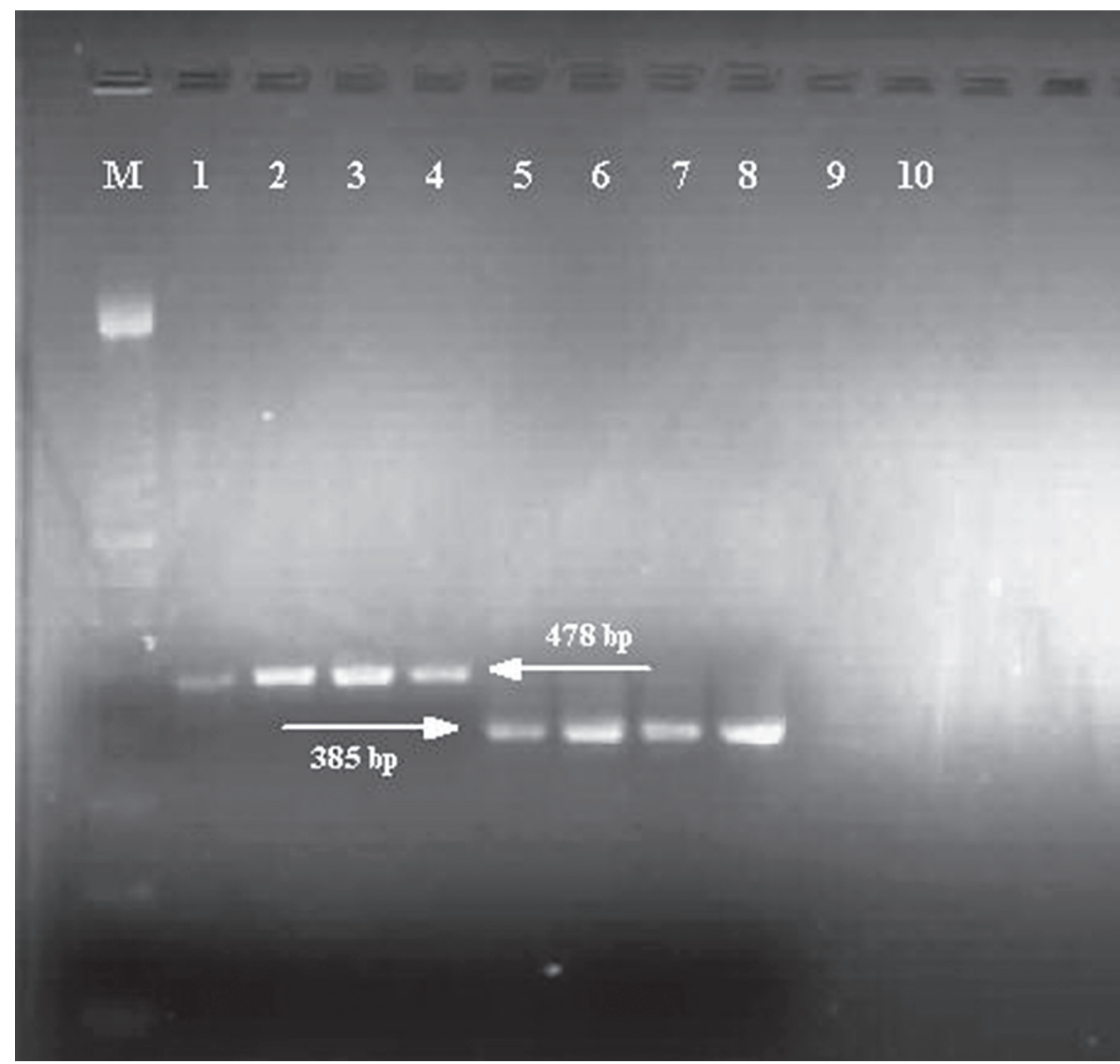

Fig 3. PCR proving DNA from 3 bulls isolates and referent Oxford strain with primers multiplying gB gen and nested PCR for the same samples. $\mathrm{M}$ - molecular size marker $1 \mathrm{~kb}$ ladder; lane 1 - isolate N 1, lane 2 - isolate N 2, lane 3 - isolate N 3, lane 4 - Oxford strain - gB gen; lane 5- isolate N 1, lane 6 - isolate N 2, lane 7-isolate N 3, lane 8 Oxford strain - gB gen nested PCR, lane 9 - control uninfected MDBK cells, lane 10 - negative control distilled water.

\section{DISCUSSION}

In the last years, ruminants' population in Bulgaria has been decreasing dramatically and the number of animals on small private farms ranges between 2 and 5, while the number of animals on big farms is 100-200. Changes in the breeding system resulted in changes of the epizootological situation in Bulgaria. Results on seroprevalence in some regions indicate that BHV 1 infection is widespread in bovine population. In our previous investigation, we established the prevalence of infection in different country regions being 16-33\% (Peshev 
et al., 2009) whereas in the current investigation revealed a higher incidence rate (38.3\%). Most probably, the reason for that is application of more sensitive ELISAs in current research than in the previous one.

Newly designed indirect BHV 1 ELISA method that we have applied for this screening is based on monoclonal antibodies with higher specificity and sensitivity, and the results can be compared with the data obtained by gB blocking ELISA or serum neutralization test (Beer et al., 2003; Isa et al., 2003). Most of the blocking and competitive reactions proving BHV 1 antibodies in infected or vaccinated animals are based on monoclonal antibodies created against epitopes of BHV $1 \mathrm{gB}$ glycoprotein. This protein is essential for BHV 1 and is highly immunogenic for infected animals. We obtained higher percentage of positive serums (cattle, calf and bulls) than in the screening test because of the using highly sensitive confirmative ELISA . Higher sensitivity of this ELISA is due to the using of corrected OD (subtraction of control uninfected cell culture OD values). It can be concluded that the use of more sensitive confirming ELISA is mandatory for such epidemiological studies.

The BHV 1 infection is easily spread from animal to animal via the respiratory or reproductive transmission route, since after native or artificial insemination semen samples are potential source of BHV 1 infection (Guerin et al. 1993). Contaminated semen samples are potential threat to bovine population because BHV 1 can cause infectious pustular vulvovaginitis, endometritis, short estrus cycles, repeat breeding, abortion in cows and balanopostitis in susceptible bulls (Schultz and Sheffy, 1980). The virus in semen participates in seminal fluids, non-sperm cells and is adsorbed on spermatozoa (Engelenburg et al. 1993). The cryoprotected semen in AIC is harvested at $-196^{\circ} \mathrm{C}$ and distributed to other country regions and farms. The distribution rate of IBR infection determined in this research is lower in regions where the number of positive bulls is also lower. The bulls can spread the virus during clinical and subclinical infection. In that respect, regular testing and control of such animals is of crucial importance.

The specific humoral immune response to BHV 1 is the result of viral infection and the specific antibody titers can persist for several years (Kashooek et al., 1996). In our research, we established high percentage of serologically positive cows in seven regions, with an average rate of OD positivity varying between 26 and 44\%, which can be as attributed to a recent BHV 1 infection. After examining the bulls originating from the same regions, we established three to four times higher average percentage of OD positive results, which strongly indicates the circulation of active BHV 1 infection among bulls' population. 
The virus isolation test on different cell culture is frequently used and is adopted as a gold standard for sensitive and specific BHV 1 detection (Edwards et al., 1983; Brunner et al., 1998). Analytical sensitivity of virus isolation varied between $<1 \mathrm{TCID}_{50}$ to $5 \mathrm{TCID}_{50} / \mathrm{mL}$. BHV1 antigen can be determined by direct or indirect immunofluorescent tests or by enzyme immune test for antigen detection. Both immunofluorescence reactions exhibit lower sensitivity as compared to the enzyme immune methods (Collins et al., 1988). We used cell cultures for BHV 1 isolation and the highly sensitive ELISA, classical and nested PCRs for the confirmation of isolated BHV 1 . Seven newly isolated strains from cows and three from bulls are an evidence for broad spreading of BHV 1 in bovine population in Bulgaria

Health status of animals depends on the raising system and the financial capacity of owners to implement the control and immunoprophylactic measures. The situation with BHV 1 distribution in different European countries is variable. The herd prevalence ranges from 10 to $80 \%$. In Portugal, the prevalence is $47.2 \%$, in dairy herds in Italy from 61 to $84 \%$, for beef herds $59 \%$ and for mixed herds $89 \%$. In Spain, the prevalence is between $38.4 \%$ and $50.4 \%$ Eiras et al. (2009). In Belgium, the positivity rate for dairy herds is $35 \%$, for beef cows $31 \%$ and for mixed herds $43 \%$ (Boelaert et al. 2000). In Lithuania, using the Pourquier (ELISA IBR-IPV gB glycoprotein antibodies) the seroprevalence rate was established to be $33.86 \%$ for cows, $8.77 \%$ for heifers and $1.69 \%$ for bulls, whereas the average percentage is $14.01 \%$.

Different European countries apply diverse strategies of BHV 1 control and eradication. In some countries, the disease is eradicated by testing and removing of positive animals. This is an expensive method and it is economically reasonable only at low level of virus infection in premises. In other countries, the protection against disease is carried out by intensive immunization programs using conventional inactivated, attenuated and gene-deleted vaccines. By the fact that the percent of infected animals in Bulgaria is high, the method for testing and removing is economically unprofitable. In Netherlands and Germany, disease control is accomplished using so-called DIVA strategy (differentiating infected from vaccinated animals) applying gene deleted vaccines and specially created tests discriminating infected from vaccinated animals. In conditions of broad distribution of infection, as in our country, this strategy can be used, and when the percentage of positive animals decreases to minimum, other positive animals can be removed from the farms. Animals imported from countries eradicating BHV 1 have to be vaccinated against BHV 1 on their farms of origin or during obligatory quarantine in the accepting country. 


\section{CONCLUSION}

1. Incidence of BHV 1 infection among bovine population in Bulgaria is high (38.8\%), which has been proved by an analysis of serum samples from 27 country regions using ELISA screening and confirmatory tests.

2. The use of more sensitive confirming ELISA is obligatory for epidemiological studies.

3. Immunoprophylactic measures against BHV 1 have to be implemented in both breeding animals and bulls.

\section{LITERATURE}

1. Beer M., Konig P., Schielke G., Trapp S.: Markerdiagnostik in der Bekämpfung des Bovinen Herpesvirus vom Typ 1: Möglichkeiten und Grenzen. Berl. Münch. Tierärztl. Wschr. 116, 5-6, 183-91, 2003.

2. Bitsch V.: The $\mathrm{P} 37 / 24$ modification of the infectious bovine rhinotracheitis virus-serum neutralization test. Acta Vet Scand., 19, 4, 497-505, 1978

3. Boelaert F., Biront P., Soumare B., Dispas M.,Vanopdenbosch E., Vermeersch J.P., Raskin A., Duffey J., Berkvens D., Kerkhofs P.: Prevalence of bovine herpesvirus-1 in the Belgian cattle population. Prev Vet Med 45, 285-295, 2000

4. Brunneer D., Engels M., Schwyzer M., Wiler R.: A comparison of three techniques for detecting bovine herpesvirus type 1 (BHV-1) in naturally and experimentally contaminated bovine semen. Zuchthygiene (Berlin), 23, 1-9, 1988

5. Collins, J.K., Ayers, V.K., Carman, J.: Evaluation of an antigen capture ELISA for the detection of bovine herpesvirus type 1 shedding from feedlot cattle. Vet Microbiol. 16, 101-107, 1988

6. Dilovski M., Haralambiev H., Tekerlekov P., Gerganov G., Diagnosis of viral disease in domestic animals. Kochov D.(ed), Zemizdat, Sofia, 1982.

7. Edwards S, Chasey D, White H.: Experimental infectious bovine rhinotracheitis: comparison of four antigen detection methods. Res Vet Sci., 34, 42-45, 1983.

8. Eiras F.J., Diéguez C., Sanjuan M.L., Yus E., Arnaiz I.: Prevalence of serum antibodies to bovine herpesvirus-1 in cattle in Galicia (NW Spain) Spanish Journal of Agricultural Research, 7, 4, 800-806, 2009.

9. Fuchs M., Hubert P., Detterer J., Rziha H.J.: Detection of bovine herpesvirus type 1 in blood from naturally infected cattle by using a sensitive PCR 
that discriminates between wild-type virus and virus lacking glycoprotein E, J. Clin. Microbiol. 37, 2498-2507, 1999.

10. Gibbs E.P., Rweyemamu M.M.: Bovine herpesviruses. I. Bovine herpesvirus 1. Veterinary Bulletin 47, 317-343, 1977.

11. Guerin G., Harlay T., Guérin B., Thibier M.: Distribution of BHV1 in fractions of semen from a naturally infected bull. Theriogenology 40, 997-1002, 1993

12. Huck R. A., Millar P. G., Evans D. H., Stables J. W., Ross, A.:. Penoposthitis associated with infectious bovine rhinotracheitis-infectious pustular vulvovaginitis (I.B.R-I.P.V.) virus in a stud of bulls. Vet. Rec. 88, 292-297, 1971

13. Isa G., Schelp C., Truyen U.: Vergleichende Untersuchung von Rinderblutproben mit drei verschiedenen BHV-1 ELISA-Tests: Indirekter ELISA und gB-Blocking-ELISAs.Berl. Münch. Tierärztl. Wschr. 116, 192 - 196, 2003

14. Kaashoek M.J., Straver P.H., Van R.E., Quak J., van Oirschot J.T.:, Virulence, immunogenicity and reactivation of seven bovine herpesvirus 1.1 strains: clinical and virological aspects. Vet. Rec. 139, 416-421, 1996.

15. Kendrick J.W., McEntee: The effect of artificial insemination with semen contaminated with IBR-IPV virus. Cornell Vet., 57, 1, 3-11, 1967

16. Kibenge F.S., Harris L.M., McKenna P.K., Wadowska D., Yason C.V.: Amplification of strains of bovine herpesvirus 1 by use of polymerase chain reaction with primers in the thymidine kinase region. Am J Vet Res. Sep, $55,9,1206-1212,1994$

17. Kramps J. A., Quak S., Weerdmeester K., van Oirschot J. T.: Comparative study on sixteen enzyme-linked immunosorbent assays for the detection of antibodies to bovine herpesvirus 1 in cattle. Vet. Microbiol. 35, 11-21, 1993.

18. Kramps J.A., Banks M., Beer M., Kerkhofs P., Perrin M., Wellenberg G.J., Van Oirschot, J.T.: Evaluation of tests for antibodies against bovine herpesvirus 1 performed in national reference laboratories in Europe. Vet Microbiol., 8, 102, 3-4, 169-81, 2004.

19. Ludwig H.:The herpesviruses. Vol 2, Ed B. Roizman. Plenum Press, NewYork, 1983.

20. Masri S. A., Olson W., Nguyen P. T., Prins S., Deregt D.: Rapid detection of bovine herpes 1 in the semen of infected bulls by a nested polymerase chain reaction assay. Can. J. Vet. Res. 60, 100-107, 1996.

21. Madic, J., Magdalena J., Quak J., Van Oirschot J.T.: Isotype specific antibody responses in sera and mucosal secretions of calves experimentally infected with bovine herpesvirus 1. Vet Immunol Immunopathol., 46, 3-4, 267-283, 1995. 
22. Sheffy B. E., Davies D. H.: Reactivation of a bovine herpesvirus after corticosteroid treatment. Proc. Soc. Exp. Biol. Med. 140, 974-976, 1972

23. Schultz R.D., Sheffy B.E.: Current status of viral infection of bovine genital tract with emphasis on IBR/IPV virus. In: Current therapy in theriogenology, ed. Morrow DA, W. B. Saunders Co., Philadelphia, PA, 503-509. 1980.

24. Roizman B., Pellett P.E.: The family Herpesviridae: A brief introduction. In: Knipe D.M., Howley P.M. (Eds.), Fields Virology, 4th ed., Lippincott Williams and Wilkins publishers, Philadelphia, 2381-2398, 2001.

25. Pastoret P.-P., Thiry E., Brochier B., Derboven G.: Bovid herpesvirus 1 infection of cattle: pathogenesis, latency, consequences of latency, Ann. Rech. Vét. 13, 221-235, 1982

26. Peshev R., Bostandjieva R.: Serological investigation of the incidence of bovine herpesvirus 1 infection in Bulgaria, Veterinary medicine, 13, 1-2, $11-15,2009$.

27. Straub O.C.: Infectious bovine rhinotracheitis virus. In: Virus Infections of Ruminants. Z Dinter and B Morein (Eds.), Elsevier Science Publishers, B.V. Amsterdam, 71-108, 1990.

28. Van Engelenburg F.A., Maes R.K., Van Oirschot J.T., Rijsewijk F.A.: Development of a rapid and sensitive polymerase chain reaction assay for detection of bovine herpesvirus type 1 in bovine semen. J Clin Microbiol., 31, 12, 3129 - 3135, 1993.

29. Van Oirschot J.T.: Infectious bovine rhinotracheitis/infectious pustular vulvovaginitis. In: Manual of Standards for Diagnostic Tests and Vaccines. 4th ed. Paris: Office International des Epizooties, 381-391, 2000.

30. Vilcek S., Nettleton P.F., Herring J.A., Herring A.J.: Rapid detection of bovine herpesvirus 1 (BHV 1) using the polymerase chain reaction. Veterinary Microbiology, 42, 53-64, 1994.

31. Wiedmann M., Brandon R., Wagner P., Dubovi E.J., Batt C.A.: Detection of bovine herpesvirus -1 in bovine semen by a nested PCR assay, J. Virol. Methods, 44, 129-140, 1993.

32. Wyler R., Engels M., Schwyzer, M.: Infectious Bovine Rhinotracheitis/ Vulvovaginitis (BHV 1). In: Wittmann G. Eds. Herpesvirus disease of cattle, horses, and pigs. Boston/Dordrecht/London: Kluwer Academic Publishers 1-72, 1989.

Primljeno: 12.12.2012.

Odobreno: 08.05.2013. 